Rapid Reviews COVID-19

\title{
Reviews of "Going Viral: The Social Credit System and COVID-19"
}

Kevin Werbach ${ }^{1}$, Marianne von Blomberg ${ }^{2}$

${ }^{1}$ University of Pennsylvania, Legal Studies and Business Ethics, USA,

${ }^{2}$ University of Cologne: Universitat zu Koln, Chair for Chinese Legal Culture, Germany

Published on: Feb 22, 2021

DOI: $10.1162 / 2 \mathrm{e} 3983 f 5.62 f 85 \mathrm{cf} 1$

License: Creative Commons Attribution 4.0 International License (CC-BY 4.0). 
To read the original manuscript, click the link above.

Summary of Reviews: Reviewers find this a reliable and important article on the complexities of the Social Credit System as a powerful tool for pandemic governance, and suggest that scholars might further consider the SCS endeavor within a broader context of Chinese "smart" state-craft.

Reviewer 1 (Kevin Werbach) |

\section{Reviewer 2 (Marianne von Blomberg) |}

\section{RR:C19 Strength of Evidence Scale Key.}

प्रिए = Misleading

प्र००० = Not Informative

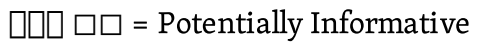

प्र०प्र = Reliable

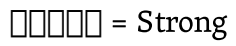

To read the reviews, click the links below. 